\title{
Potential Yield of Soybean Lines Are Higher Than Their Parent Indonesian Lowland Popular Variety
}

\author{
Heru Kuswantoro $^{1}$ \\ ${ }^{1}$ Indonesian Legume and Tuber Crops Research Institute, Indonesian Agency for Agricultural Research and \\ Development, Indonesia
}

Correspondence: Heru Kuswantoro, Indonesian Legume and Tuber Crops Research Institute, Indonesian Agency for Agricultural Research and Development, Malang, Indonesia. E-mail: herukusw@yahoo.com

$\begin{array}{lc}\text { Received: July 11, } 2013 & \text { Accepted: January 9, } 2014 \quad \text { Online Published: February 12, } 2014 \\ \text { doi:10.5539/ijb.v6n2p49 } & \text { URL: http://dx.doi.org/10.5539/ijb.v6n2p49 }\end{array}$

\begin{abstract}
Breeding materials should be evaluated under a number of different environments, to ensure their genetic value. The objective of the research was to study the potential yield of soybean lines compared to the parent in two environments. A total of 15 genotypes (including one Indonesian lowland popular variety, 'Anjasmoro') were grown in Jambegede (Entisol-Inceptisol association) and Ngale (Vertisol) Research Stations in June-September 2011. The design was a randomized completely blocks design with three replications. The results showed that $\mathrm{G}$ $\times \mathrm{E}$ interaction highly affected the grain yield causing different rank for the genotypes in different environment. Tgm/Anj-795 and Tgm/Anj-790 lines consistently yielded the highest grain in both environments. Tgm/Anj-790 also had large seed size. Tgm/Anj-789 and Tgm/Anj-796 consistently showed the earliest days to maturity in both environments. 'Anjasmoro' had longer days to maturity but lower grain yield. Tgm/Anj-795 and Tgm/Anj-790 lines had potentially high yield stability that need to be tested further in many different environments to gain knowledge of their actual yield stability.
\end{abstract}

Keywords: agronomic characters, $\mathrm{G} \times \mathrm{E}$ interaction, soybean lines, yield

\section{Introduction}

The main goal of growing crops is to maximize net profit through increasing grain yield (Alghamdi, 2004). Hence, the primary goal of most soybean breeding programs is high grain yield (Toledo et al., 2000). To increase soybean growth area and production, it is also important to develop the high-yielding early-maturing cultivars under a wide range of different environments (Alghamdi, 2004). For sustainable agriculture, the use of stable genotypes as a mean of high grain yield is very important (Carpenter \& Board, 1997). In Indonesia the soybean production always decreases due to the decresing planting area (Statistic Indonesia, 2013). Therefore, high grain yield soybean variety is needed to maintain or increase soybean production.

In developing an improved variety, the genotype vs environment interaction $(G \times E)$ is of major importance (Sharrifmoghaddassi \& Omiditabrizi, 2010). Trait stability parameters are estimated to determine the superiority of individual genotypes across the range of environments when the $\mathrm{G} \times \mathrm{E}$ is the present (Ulker et al., 2006); but in the absence of information on $\mathrm{G} \times \mathrm{E}$, estimation of heritability and prediction of genetic advance become biased. Hence, breeding material should be evaluated under different environments (Duzdemir, 2011). Information on $\mathrm{G} \times \mathrm{E}$ is very important in selecting and developing variety that will be recommended in a certain area. The $\mathrm{G} \times \mathrm{E}$ occurs when variability relative or rank of a genotype change with the environment change. The interaction of genotype and environment can also be described as the interplay between genetic and environmental factors on the growth and development of plants (Cucolotto et al., 2007). Thus, a high-yielding variety in an area does not necessarily have high yields in other areas and vice versa.

Yield stability of a plant in certain area will be different from other area and dependent on the environmental conditions of its both abiotic and biotic environment. Comparatively, the abiotic/physical environmental conditions such as soil type, rainfall, temperature, and humidity play a greater role on the stability of crop yields than that of biotic environmental conditions; because abiotic environmental condition always exist in longterm period than biotic condition. Beside, biotic condition, such as disease and pest infestation, is an incidental condition. Therefore, plant breeders always test their promising lines in various environments, to determine the yield stability of the candidate varieties to be released. Promising lines that were assessed stable in various 
environments are released as varieties for broad areas. Promising lines having the highest yield potential in a particular area are classified as unstable lines, and can be recommended for narrow adaptation (Gurmu et al., 2009).

Stability is defined as the ability of plants to maintain its yield potential under the changing of environmental conditions, so the stability is dynamic in character and always changes based on a specific range of different environments (Hidayat, 2002). From the agronomic point of view, stability follows the homeostatic processes of living organisms in the short term to maintain productivity under environmental changes. In this sense, stability is characterized by high sustainability and equitability (Conway, 1982). In this experiment, soybean lines were tested in two different environments to study their potential yield compared to the Indonesian lowland popular variety ('Anjasmoro').

\section{Materials and Method}

A total of 14 soybean (Glycine $\max$ (L.) Merrill) lines which derived of 'Tanggamus' and 'Anjasmoro' crossing, and one of the parents (Indonesian lowland popular variety, 'Anjasmoro') were grown on lowland with "Rice-Rice-Soybean" cropping pattern at Jambegede Research Station and Ngale Research Station from June to September 2011. Crossing was conducted at Indonesian Legume and Tuber Crops Institute, Malang, in 2005 by using 'Tanggamus' as female parent and 'Anjasmoro' as male parent. Jambegede Research Station is located on Malang Regency, East Java Province, while Ngale Research Station is located on Ngawi Regency, East Java Province. Soil type of Jambegede Research Station is Entisol-Inceptisol association, while Ngale Research Station is Vertisol. Climate type of both environments is C3 according to Oldeman classification (Oldeman, 1975), where there are 5-6 wet months and 4-6 dry months. The altitude for Jambegede and Ngale Research Station are $335 \mathrm{~m}$ and $168 \mathrm{~m}$ above sea level, respectively.

The design was a randomized complete blocks design with three replications. The plot size was $1.6 \mathrm{~m} \times 3.0 \mathrm{~m}$ with plant spacing of $0.4 \mathrm{~m} \times 0.15 \mathrm{~m}$, two plants per hill. Fertilization was done by applying $50 \mathrm{~kg}$ Urea, $75 \mathrm{~kg}$ SP36, and $75 \mathrm{~kg}$ of $\mathrm{KCl}$ per hectare at sowing time. Weeding was conducted manually at 14 and 28 day after planting (dap). Watering was conducted by technical irrigation. Pest control was intensively done by applying insecticides with 5 days interval. Harvesting was carried out after the plant was physiologically matured, that was shown by pods having turned to yellow/brown and the leaves fallen. Data were collected for $50 \%$ days to flowering, days to maturity, plant height, number of branches per plant, number of pods per plant, 100 grains weight, and grain yield per hectare.

\section{Results and Discusion}

Results showed that there were interactions between the genotypes and environment regarding the grain yield, flowering and days to maturity, and number of branches (Table 1). Similar results were reported by Ashraf et al. (2010) and Jandong et al. (2011). This indicates that there was a difference in the response of the lines tested against the growth environment. Comparatively, there was no statistical siginificant $\mathrm{G} \times \mathrm{E}$ regarding plant height, number of pods per plant, and weight of 100 grains, but significant differences among the tested genotypes were acquired for three characters. This indicates that there existed diversity among the tested lines.

Table 1. Genetic $\times$ environment $(\mathrm{G} \times \mathrm{E})$ analysis of soybean lines at Jambegede and Ngale Research Stations. Dry season 2011

\begin{tabular}{lcccccccc}
\hline Source & Degree of freedom & Flower & Maturity & Height & Branches & Pod-f & $100 S W$ & Yield \\
\hline Environments & 1 & $405.34^{* *}$ & $182.04^{* *}$ & $1,418.22^{* *}$ & 0.78 & 422.50 & 16.73 & 1.57 \\
Genotypes & 14 & $37.95^{* *}$ & $91.82^{* *}$ & $236.02^{* *}$ & $2.48^{* *}$ & $248.25^{* *}$ & $11.51^{* *}$ & $0.55^{* *}$ \\
$\mathrm{G} \times \mathrm{E}$ & 14 & $3.80^{* *}$ & $36.62^{* *}$ & 32.93 & $0.69^{* *}$ & 48.97 & 1.20 & $0.22^{*}$ \\
Error & 1 & 0.68 & 60.09 & 18.59 & 0.27 & 65.27 & 1.18 & 0.10 \\
\hline Coefficient of variation (\%) & 2.42 & 1.30 & 7.74 & 13.11 & 14.84 & 8.49 & 16.16
\end{tabular}

**Significant at 1\%, *Significant at 5\%, Flower $=$ flowering indices, Maturity $=$ maturity indices, Height $=$ plant height $[\mathrm{cm}]$, Branches $=$ number of branches per plant, Pod-f $=$ number of pods per plant, $100 \mathrm{GW}=100$ grains weight, Yield = yield per hectare. 
Tgm/Anj-790 line had the highest grain yield (2.53 t/ha) in Jambegede, whereas Tgm/Anj-795 line had the highest grain yield (2.50 t/ha) at Ngale (Table 2). 'Anjasmoro' as control variety yielded much lower yield, in Jambegede and Ngale i.e. 1.50 and $1.71 \mathrm{t} /$ ha respectively, than either of those two best-yielding lines. Lines that had lower grain than 'Anjasmoro' were Tgm/Anj-777, Tgm/Anj-789, Tgm/Anj-803 and Tgm/Anj-824 grown at Jambegede (Table 2). At Ngale, no line had lower yield than 'Anjasmoro'. Furthermore, Tgm/Anj-789 had low grain yield (1.28 t/ha) at Jambegede, but at Ngale was quite high yield (2.13 t/ha) (Table 2). Average grain yield of Ngale was higher than that of Jambegede, i.e. 2.09 and $1.83 \mathrm{t} / \mathrm{ha}$ respectively. It may be due to the varying level of availability of the soil moisture, since at Ngale, the soil moisture was presumed higher than at Jambegede. Indeed the soil type of Ngale is Vertisol, able to retain more water than soil type of Jambegede (Entisol-Inceptisol association). On the other hand, the average grain yield obtained in this experiment was higher than these in analogical studies in tropical areas (Aremu et al., 2006), but lower than in subtropical areas (De Bruin \& Pedersen, 2009; Pedersen \& Lauer, 2004; Wilhelm \& Wortmann, 2004).

Table 2. Grain yield of soybean lines at Jambegede and Ngale Research Stations. Dry season 2011

\begin{tabular}{lll}
\hline \multirow{2}{*}{ Genotypes } & Yield [t/ha] & \\
\cline { 2 - 3 } & Jambegede & Ngale \\
\hline Tgm/Anj-743 & $2.25 \mathrm{a}-\mathrm{d}$ & $2.17 \mathrm{a}-\mathrm{f}$ \\
Tgm/Anj-744 & $1.95 \mathrm{c}-\mathrm{i}$ & $2.15 \mathrm{a}-\mathrm{f}$ \\
Tgm/Anj-764 & $2.01 \mathrm{~b}-\mathrm{i}$ & $2.19 \mathrm{a}-\mathrm{f}$ \\
Tgm/Anj-773 & $2.32 \mathrm{a}-\mathrm{d}$ & $2.34 \mathrm{a}-\mathrm{d}$ \\
Tgm/Anj-777 & $1.22 \mathrm{j}$ & $1.88 \mathrm{c}-\mathrm{i}$ \\
Tgm/Anj-778 & $2.21 \mathrm{a}-\mathrm{e}$ & $1.96 \mathrm{c}-\mathrm{i}$ \\
Tgm/Anj-780 & $1.63 \mathrm{~g}-\mathrm{j}$ & $2.37 \mathrm{a}-\mathrm{c}$ \\
Tgm/Anj-789 & $1.28 \mathrm{j}$ & $2.13 \mathrm{a}-\mathrm{g}$ \\
Tgm/Anj-790 & $2.53 \mathrm{a}$ & $2.31 \mathrm{a}-\mathrm{d}$ \\
Tgm/Anj-795 & $2.24 \mathrm{a}-\mathrm{d}$ & $2.50 \mathrm{ab}$ \\
Tgm/Anj-796 & $2.07 \mathrm{a}-\mathrm{h}$ & $1.84 \mathrm{~d}-\mathrm{i}$ \\
Tgm/Anj-799 & $1.60 \mathrm{~h}-\mathrm{j}$ & $1.99 \mathrm{~b}-\mathrm{i}$ \\
Tgm/Anj-803 & $1.31 \mathrm{j}$ & $1.67 \mathrm{f}-\mathrm{j}$ \\
Tgm/Anj-824 & $1.29 \mathrm{j}$ & $2.17 \mathrm{a}-\mathrm{f}$ \\
'Anjasmoro' & $1.50 \mathrm{ij}$ & $1.71 \mathrm{e}-\mathrm{j}$ \\
\hline LSD 5\% & 0.52 &
\end{tabular}

Values followed by the same letter were not significantly different at Least Significant Different (LSD) 5\%.

Tgm/Anj-744 and Tgm/Anj-824 lines scored the longest days to flowering periods both at Jambegede and at Ngale (Table 3). Line with the shortest days to flowering planted at Ngale was Tgm/Anj-789 (29 days). At Jambegede, line with the shortest days to flowering was Tgm/Anj-795 (32 days). 'Anjasmoro' scored days to flowering of 33 days and 31 days at Jambegede and Ngale, respectively. In general, days to flowering counts scored for soybean lines grown at Jambegede were higher than for those grown at Ngale. In this study, days to flowering values did not correlate with yield (data not shown), but in another study (Egli \& Bruening, 2002) with the time of flower development and pollination being possibly an important determinant of seed number.

Tgm/Anj-773 and Tgm/Anj-790 lines scored the highest values of days to maturity indices at Jambegede (Table 3). At Ngale, the tested lines had a generally relatively lower values of days to flowering indices, while 'Anjasmoro' had the highest value of day to maturity at this location (Table 3). Tgm/Anj-789 and Tgm/Anj-796 consistently showed the lowest value of days to maturity at both environments. Similar to days to flowering indices' value, the days to maturity indices of soybean lines grown at Jambegede scored higher than these at Ngale. Variety 'Anjasmoro', with the highest value of days to maturity, did not give the highest yield. It might be due to the higher use of photosyntates for vegetative growth for this higher scoring days to maturity indices. The 
higher vegetative growth may decrease grain yield because higher vegetative growth will affect leaf area index. Similar result also showed by Mellendorf (2011) which reported that in higher plant density lead decreasing grain yield.

The highest number of branches per plant was developed by Tgm/Anj-803 line grown at Jambegede, and equivalent to Tgm/Anj-778 line grown at Ngale Research Station. At the same time, the lowest branches per plant index was shown by 'Anjasmoro' in both locations, and equivalent to Tgm/Anj-780 at Jambegede and Tgm/Anj-789 at Ngale (Table 4). The number of branches per plant was related to grain yield, similar to report by Machikowa and Laosuwan (2011), who stated that number of branches per plant gives the highest positive direct effect on grain yield per plant after number of pods per plant.

Table 3. Days to flowering and maturity of soybean lines at Jambegede and Ngale Research Stations. Dry season 2011

\begin{tabular}{lllll}
\hline \multirow{2}{*}{ Genotypes } & \multicolumn{2}{l}{ Days to flowering [days] } & \multicolumn{2}{l}{ Days to maturity [days] } \\
\cline { 2 - 5 } & Jambegede & Ngale & Jambegede & Ngale \\
\hline Tgm/Anj-743 & $38.6 \mathrm{~b}$ & $33.0 \mathrm{gh}$ & $82.7 \mathrm{ab}$ & $78.7 \mathrm{~g}-\mathrm{i}$ \\
Tgm/Anj-744 & $40.3 \mathrm{a}$ & $38.0 \mathrm{bc}$ & $81.3 \mathrm{~b}-\mathrm{d}$ & $78.0 \mathrm{~h}-\mathrm{j}$ \\
Tgm/Anj-764 & $38.0 \mathrm{bc}$ & $34.0 \mathrm{fg}$ & $79.0 \mathrm{f}-\mathrm{i}$ & $76.7 \mathrm{j}$ \\
Tgm/Anj-773 & $35.0 \mathrm{ef}$ & $31.0 \mathrm{ij}$ & $84.0 \mathrm{a}$ & $79.3 \mathrm{e}-\mathrm{h}$ \\
Tgm/Anj-777 & $37.0 \mathrm{~cd}$ & $31.0 \mathrm{ij}$ & $80.7 \mathrm{c}-\mathrm{f}$ & $76.7 \mathrm{j}$ \\
Tgm/Anj-778 & $36.7 \mathrm{~cd}$ & $30.0 \mathrm{jk}$ & $81.7 \mathrm{bc}$ & $79.3 \mathrm{e}-\mathrm{h}$ \\
Tgm/Anj-780 & $33.0 \mathrm{gh}$ & $30.0 \mathrm{jk}$ & $81.0 \mathrm{~b}-\mathrm{e}$ & $79.3 \mathrm{e}-\mathrm{h}$ \\
Tgm/Anj-789 & $33.3 \mathrm{gh}$ & $29.0 \mathrm{k}$ & $79.7 \mathrm{~d}-\mathrm{h}$ & $77.3 \mathrm{ij}$ \\
Tgm/Anj-790 & $35.7 \mathrm{de}$ & $31.0 \mathrm{ij}$ & $83.7 \mathrm{a}$ & $78.0 \mathrm{hij}$ \\
Tgm/Anj-795 & $32.7 \mathrm{gh}$ & $30.0 \mathrm{jk}$ & $80.7 \mathrm{c}-\mathrm{f}$ & $79.3 \mathrm{e}-\mathrm{h}$ \\
Tgm/Anj-796 & $35.7 \mathrm{de}$ & $32.0 \mathrm{hi}$ & $79.7 \mathrm{~d}-\mathrm{h}$ & $77.3 \mathrm{ij}$ \\
Tgm/Anj-799 & $37.3 \mathrm{bc}$ & $31.0 \mathrm{ij}$ & $81.7 \mathrm{bc}$ & $78.0 \mathrm{~h}-\mathrm{j}$ \\
Tgm/Anj-803 & $38.0 \mathrm{bc}$ & $32.0 \mathrm{hi}$ & $80.7 \mathrm{c}-\mathrm{f}$ & $79.3 \mathrm{e}-\mathrm{h}$ \\
Tgm/Anj-824 & $40.3 \mathrm{a}$ & $38.0 \mathrm{bc}$ & $81.0 \mathrm{~b}-\mathrm{e}$ & $78.7 \mathrm{ghi}$ \\
‘Anjasmoro' & $33.0 \mathrm{gh}$ & $31.0 \mathrm{ij}$ & $81.3 \mathrm{~b}-\mathrm{d}$ & $80.0 \mathrm{c}-\mathrm{g}$ \\
\hline LSD 5\% & 1.35 & & 1.69 &
\end{tabular}

Values followed by the same letter were not significantly different at Least Significant Different (LSD) $5 \%$. 
Table 4. Number of branches per plant of soybean lines at the Jambegede and the Ngale Research Stations. Dry season 2011

\begin{tabular}{lll}
\hline \multirow{2}{*}{ Genotypes } & \multicolumn{2}{c}{ Number of branches/plant } \\
\cline { 2 - 3 } & Jambegede & Ngale \\
\hline Tgm/Anj-743 & $3.63 \mathrm{~g}-\mathrm{m}$ & $4.77 \mathrm{a}-\mathrm{d}$ \\
Tgm/Anj-744 & $4.43 \mathrm{a}-\mathrm{g}$ & $3.17 \mathrm{j}-\mathrm{n}$ \\
Tgm/Anj-764 & $4.70 \mathrm{a}-\mathrm{d}$ & $4.57 \mathrm{a}-\mathrm{e}$ \\
Tgm/Anj-773 & $3.83 \mathrm{e}-\mathrm{k}$ & $3.67 \mathrm{f}-\mathrm{m}$ \\
Tgm/Anj-777 & $3.97 \mathrm{~d}-\mathrm{j}$ & $4.03 \mathrm{~d}-\mathrm{i}$ \\
Tgm/Anj-778 & $4.03 \mathrm{~d}-\mathrm{i}$ & $5.13 \mathrm{ab}$ \\
Tgm/Anj-780 & 2.97 l-n & $3.73 \mathrm{e}-\mathrm{l}$ \\
Tgm/Anj-789 & $3.27 \mathrm{i}-\mathrm{m}$ & $2.93 \mathrm{l}-\mathrm{n}$ \\
Tgm/Anj-790 & $3.77 \mathrm{e}-1$ & $4.30 \mathrm{~b}-\mathrm{g}$ \\
Tgm/Anj-795 & $3.00 \mathrm{k}-\mathrm{n}$ & $4.20 \mathrm{c}-\mathrm{h}$ \\
Tgm/Anj-796 & $3.60 \mathrm{~g}-\mathrm{m}$ & $3.37 \mathrm{~h}-\mathrm{m}$ \\
Tgm/Anj-799 & $4.23 \mathrm{c}-\mathrm{g}$ & $4.30 \mathrm{~b}-\mathrm{g}$ \\
Tgm/Anj-803 & $5.23 \mathrm{a}$ & $4.90 \mathrm{a}-\mathrm{c}$ \\
Tgm/Anj-824 & $4.50 \mathrm{a}-\mathrm{f}$ & $4.40 \mathrm{a}-\mathrm{g}$ \\
'Anjasmoro' & $2.37 \mathrm{n}$ & $2.87 \mathrm{mn}$ \\
\hline LSD 5\% & 0.84 &
\end{tabular}

Values followed by the same letter were not significantly different at Least Significant Different (LSD) 5\%.

No $G \times E$ was found for plant height (Table 1). In Jambegede and Ngale the highest plant height was shown by Tgm/Anj-744 (60.1 cm and $78.3 \mathrm{~cm}$ respectively). The shortest plant height was shown by Tgm/Anj-780 and Tgm/Anj-789 in Jambegede and Tgm/Anj-789 in Ngale (Table 5). 'Anjasmoro' had the plant height slightly below the average of the tested lines, i.e. $50 \mathrm{~cm}$ in Jambegede and $58.9 \mathrm{~cm}$ in Ngale. Plant height is important for other agronomic traits, because it correlates with those agronomic traits such as number of branches per plant, number of pods per plant, and grain yield of soybean (Kuswantoro et al., 2006). Moreover, Board (2002) suggested a regression model to predict the high-yielding cultivars and correlated it with yield per plot based on plant height, in addition to total dry matter at beginning seed (reproductive stage 5 - R5) and pod filling period. 
Table 5. Plant height of per plant of soybean lines at the Jambegede and the Ngale Research Stations. Dry season 2011

\begin{tabular}{lll}
\hline \multirow{2}{*}{ Genotypes } & \multicolumn{2}{c}{ Plant height [cm] } \\
\cline { 2 - 3 } & Jambegede & Ngale \\
\hline Tgm/Anj-743 & $53.8 \mathrm{~b}-\mathrm{d}$ & $56.0 \mathrm{bd}$ \\
Tgm/Anj-744 & $60.1 \mathrm{a}$ & $78.3 \mathrm{a}$ \\
Tgm/Anj-764 & $55.8 \mathrm{a}-\mathrm{d}$ & $60.1 \mathrm{~b}$ \\
Tgm/Anj-773 & $45.5 \mathrm{ef}$ & $60.2 \mathrm{~b}$ \\
Tgm/Anj-777 & $45.0 \mathrm{ef}$ & $56.7 \mathrm{~b}-\mathrm{d}$ \\
Tgm/Anj-778 & $53.0 \mathrm{~cd}$ & $60.3 \mathrm{~b}$ \\
Tgm/Anj-780 & $40.0 \mathrm{f}$ & $51.1 \mathrm{~cd}$ \\
Tgm/Anj-789 & $41.4 \mathrm{f}$ & $49.0 \mathrm{~d}$ \\
Tgm/Anj-790 & $56.9 \mathrm{a}-\mathrm{c}$ & $61.5 \mathrm{~b}$ \\
Tgm/Anj-795 & $51.7 \mathrm{~cd}$ & $57.0 \mathrm{~b}-\mathrm{d}$ \\
Tgm/Anj-796 & $52.7 \mathrm{~cd}$ & $54.6 \mathrm{~b}-\mathrm{d}$ \\
Tgm/Anj-799 & $59.5 \mathrm{ab}$ & $70.2 \mathrm{a}$ \\
Tgm/Anj-803 & $54.9 \mathrm{a}-\mathrm{d}$ & $61.5 \mathrm{~b}$ \\
Tgm/Anj-824 & $56.2 \mathrm{a}-\mathrm{c}$ & $59.9 \mathrm{~b}$ \\
'Anjasmoro' & $50.0 \mathrm{de}$ & $58.9 \mathrm{bc}$ \\
\hline LSD 5\% & 5.96 & 8.28
\end{tabular}

Values in the same column followed by the same letter were not significantly different at Least Significant Different (LSD) $5 \%$.

The highest number of pods per plant developed the Tgm/Anj-773, while the lowest the Tgm/Anj-789 (Table 6). 'Anjasmoro' also classified as genotype with the lowest number of pods after Tgm/Anj-790 (Table 6). Genetic factors play a greater role in expression of these traits because there was no interaction with the environment (Table 1). Inadequate supply of assimilates to flowers is a dominant factor in flower abortion (Yashima et al., 2005), causing pod number reduction. Machikowa and Laosuwan (2011) reported that pods per plant count had the highest positive direct effect on grain yield. The number of pods per plant was reported as largely dependent on the number of floral buds that initiate pods (Desclaux et al., 2000). There was a significant correlation found between the number of pods per plant and grain yield (Malik et al., 2011). Furthermore, number of pods per plant was reported as having a positive direct effect on grain yield (Machikowa \& Laosuwan, 2011; Sudaric \& Vrataric, 2002).

Grain size was expressed as the weight of 100 grains and presented in Table 6. The largest seed size was achieved by Tgm/Anj-790, while the smallest seed size by Tgm/Anj-764. Environment markedly influences seed size during the seed development period of growth (Table 1). At the seed development period, grain size reduction caused by drought or other stresses can substantially reduce yield (Kuswantoro \& Zen, 2013). Nevertheles, several smaller-seeded soybean lines with high yields have been reported and vice versa, which indicates that seed size does not directly correlate with yield potential (Klein et al., 2005). Some researchers obtained different results with a significant correlation (Malik et al., 2011) and a genetic correlation (Arshad et al. 2006) was found between grain yield and 100 grains weight. Also, 100 grains weight had a positive direct effect on grain yield (El-Badawy \& Mehasen, 2012). 
Table 6. Average of number of filled pods per plant and 100 grain weight of soybean lines at the Jambegede and the Ngale Research Stations. Dry season 2011

\begin{tabular}{lll}
\hline Genotypes & Number of filled pods/plant & Grain weight [g/100 grains] \\
\hline Tgm/Anj-743 & $62.62 \mathrm{ab}$ & $11.17 \mathrm{fg}$ \\
Tgm/Anj-744 & $56.02 \mathrm{a}-\mathrm{d}$ & $12.51 \mathrm{c}-\mathrm{e}$ \\
Tgm/Anj-764 & $54.17 \mathrm{~b}-\mathrm{e}$ & $10.58 \mathrm{~g}$ \\
Tgm/Anj-773 & $63.80 \mathrm{a}$ & $11.72 \mathrm{e}-\mathrm{g}$ \\
Tgm/Anj-777 & $50.52 \mathrm{c}-\mathrm{e}$ & $13.71 \mathrm{bc}$ \\
Tgm/Anj-778 & $60.28 \mathrm{ab}$ & $11.84 \mathrm{~d}-\mathrm{f}$ \\
Tgm/Anj-780 & $49.48 \mathrm{c}-\mathrm{e}$ & $12.87 \mathrm{~b}-\mathrm{e}$ \\
Tgm/Anj-789 & $45.10 \mathrm{e}$ & $13.02 \mathrm{~b}-\mathrm{d}$ \\
Tgm/Anj-790 & $47.30 \mathrm{de}$ & $14.04 \mathrm{~b}$ \\
Tgm/Anj-795 & $49.15 \mathrm{c}-\mathrm{e}$ & $13.34 \mathrm{bc}$ \\
Tgm/Anj-796 & $49.20 \mathrm{c}-\mathrm{e}$ & $12.71 \mathrm{c}-\mathrm{e}$ \\
Tgm/Anj-799 & $62.60 \mathrm{ab}$ & $13.40 \mathrm{bc}$ \\
Tgm/Anj-803 & $60.88 \mathrm{ab}$ & $12.00 \mathrm{~d}-\mathrm{f}$ \\
Tgm/Anj-824 & $57.38 \mathrm{a}-\mathrm{c}$ & $12.57 \mathrm{c}-\mathrm{e}$ \\
'Anjasmoro' & $48.30 \mathrm{c}-\mathrm{e}$ & $16.45 \mathrm{a}$ \\
\hline LSD 5\% & 9.34 & 1.26 \\
\hline
\end{tabular}

Values in the same column and followed by the same letter were not significantly different at Least Significant Different (LSD) $5 \%$.

\section{Conclusion}

The grain yield was highly affected by $\mathrm{G} \times \mathrm{E}$ interaction. In the different environment, ranking of the genotypes were also different. However, Tgm/Anj-795 and Tgm/Anj-790 lines consistently had the highest grain yield in both locations. Tgm/Anj-790 high yield was defined by the large seed size. The $\mathrm{G} \times \mathrm{E}$ interaction also affected other traits, such as days to flowering indices, days to maturity indices, and number of branches per plant. Tgm/Anj-789 and Tgm/Anj-796 consistently showed the lowest values of days to maturity in both locations. 'Anjasmoro' had higher value of days to maturity but lower grain yield. Tgm/Anj-795 and Tgm/Anj-790 lines had potentially high yield stability that need to be further tested in many different locations and seasons to know the actual stability.

\section{Acknowledgements}

This study was funded by the State Ministry of Research and Technology of Republic of Indonesia through SINTA Project 2011. Thank Mr. Agus Supeno for the assistance in the research.

\section{References}

Alghamdi, S. S. (2004). Yield stability of some soybean genotypes across diverse environments. Pak. J. Biol. Sci., 7, 2109-2114. http://dx.doi.org/10.3923/pjbs.2004.2109-2114

Aremu, C. O., Ojo, D. K., Oduwaye, O. A., \& Amira, J. O. (2006). Comparison of joint regression analysis (JRA) and additive main effect and multiplicative interaction (AMMI) model in the study of $\mathrm{G} \times \mathrm{E}$ interaction in soybean. Nigerian J. Genet., 20, 74-83.

Arshad, M., Ali, N., \& Ghafoor, A. (2006). Character correlation and path coefficient in soybean Glycine max (L.) Merrill. Pak. J. Bot., 38, 121-130.

Ashraf, M., Iqbal, Z., Arshad, M., Waheed, A., Gufran, M. A., Chaudhry, Z., \& Baig, D. (2010). Multi-environment response in seed yield of soybean [Glycine max (L.) Merrill], genotypes through GGE biplot technique. Pak. J. Bot., 42, 3899-3905. 
Board, J. E. (2002). A regression model to predict soybean cultivar yield performance at late planting dates. Agron. J., 94, 483-492. http://dx.doi.org/10.2134/agronj2002.0483

Carpenter, A. C., \& Board, J. E. (1997). Branch yield components controlling soybean yield stability across plant populations. Crop Sci., 37, 885-891. http://dx.doi.org/10.2135/cropsci1997.0011183X003700030031x

Conway, G. (1982). A Guide to Agroecosystem Analysis. Multiple Croping Project. Thailand: Faculty of Agriculture. University of Chiang Mai.

Cucolotto, M., Pípolo, V. C., Garbuglio, D. D., da S. F. Junior, N., Destro, D., \& Kamikoga, M. K. (2007). Genotype $\mathrm{x}$ environment interaction in soybean: evaluation through three methodologies. Crop Breeding and Applied Biotechnology, 7, 270-277.

De Bruin, J. L., \& Pedersen, P. (2009). Growth, yield, and yield component changes among old and new soybean cultivars. Agron. J., 101, 124-130. http://dx.doi.org/10.2134/agronj2008.1087

Desclaux, D., Huynh, T. T., \& Roumet, P. (2000). Identification of soybean plant characteristics that indicate the timing of drought stress. Crop Sci., 40, 716-722. http://dx.doi.org/ 10.2135/cropsi2000.403716x

Duzdemir, O. (2011). Stability analysis for phenological characteristics in chickpea. Afr. J. Agric. Res., 6, 1682-1685. http://dx.doi.org/ 10.5897/AJAR10.1138

Egli, D. P., \& Bruening, W. P. (2000). Potential of early-maturing soybean cultivars in late plantings. Agron. J., 92, 532-537. http://dx.doi.org/10.2134/agronj2000.923532x

Egli, D. P., \& Bruening, W. P. (2002). Synchronous flowering and fruit set at phloem-isolated nodes in soybean. Crop Sci., 42, 1535-1540. http://dx.doi.org/ 10.2135/cropsci2002.1535

El-Badawy, M. El. M., \& Mehasen, S. A. S. (2012). Correlation and path coefficient analysis for yield and yield components of soybean genotypes under different planting density. Asian J. Crop Sci., 4, 150-158. http://dx.doi.org/10.3923/ajcs.2012.150.158

Gurmu, F., Mohammed, H., \& Alemaw, G. (2009). Genotype x environment interactions and stability of soybean for grain yield and nutrition quality. African Crop Sci. Journal, 17, 87-99.

Hidayat. (2002). Analisis Interaksi Galur Lingkungan Beberapa Galur Padi Di Lahan Pasang Surut Berjenis Tanah Gambut Kalimantan Barat. Disertasi Doktor. Program Pascasarjana Universitas Gadjah Mada. Yogyakarta.

Jandong, E. A., Uguru, M. I., \& Oyiga, B. C. (2011). Determination of yield stability of seven soybean (Glycine max) genotypes across diverse soil pH levels using GGE biplot analysis. J. of Appl. Biosci., 43, 2924-2941.

Klein, R., Elmore, R. W., \& Nelson, L. A. (2005). Using Soybean Yield Data to Improve Variety Selection - Part I. University of Nebraska - Lincoln Extension educational programs abide with the nondiscrimination policies of the University of Nebraska - Lincoln and the United States Department of Agriculture.

Kuswantoro, H., Basuki, N., \& Arsyad., D. M. (2006). Identifikasi plasma nutfah kedelai toleran terhadap tanah masam berdasarkan keragaman genetik dan fenotipik. Agrivita, 28, 54-63.

Kuswantoro, H., \& Zen, S. (2013). Performance of acid-tolerant soybean promising lines in two planting seasons. Inter. J. Biol., 5, 49-56. http://dx.doi.org/10.5539/ijb.v5n3p49

Machikowa, T. \& Laosuwan, P. (2011). Path coefficient analysis for yield of early maturing soybean. Songklanakarin J. Sci. Technol., 33, 365-368.

Malik, M. F. A., Ashraf, M., Qureshi, A. S., \& Khan, M. R. (2011). Investigation and comparison of some morphological traits of the soybean populations using cluster analysis. Pak. J. Bot., 43, 1249-1255.

Oldeman, L. R. (1975). An agro-climatic map of Java. Central Research Institute for Agriculture. Bogor, Indonesia.

Pedersen, P., \& Lauer, J. G. (2004). Response of soybean yield components to management system and planting date. Agron. J., 96, 1372-1381. http://dx.doi.org/10.2134/agronj2004.1372

Sharrifmoghaddassi, M., \& Omiditabrizi, A. H. (2010). Stability analysis of seven Iranian Winter safflower cultivars. World Applied Sci. J., 8, 1366-1369.

Statistic Indonesia. (2013). Trends of Selected Socio-Economic Indicators of Indonesia. BPS - Statistic Indonesia. Jakarta.

Sudaric, A., \& Vrataric, M. (2002). Variability and interrelationships of grain quantity and quality characteristics 
in soybean. Die Bodenkultur, 53, 137-142.

Toledo, J. F. F. de, Arias, C. A. A., Oliveira, M. F. de, Triller, C., \& Miranda, Z. de F. S. (2000). Genetical and environmental analyses of yield in six biparental soybean crosses. Pesq. agropec. bras., Brasília, 35, 1783-1796. http://dx.doi.org/10.1590/S0100-204X2000000900011

Ülker, M., Sönmez, F., Çiftçi, V., Yilmaz, N., \& Apak, R. (2006). Adaptation and stability analysis in the selected lines of tir wheat. Pak. J. Bot., 38, 1177-1183.

Wilhelm, W. W., \& Wortmann, C. S. (2004). Tillage and rotation interactions for corn and soybean grain yield as affected by precipitation and air temperature. Agron. J., 96, 425-432. http://dx.doi.org/10.2134/agronj2004.4250

Yashima, Y., Kaihatsu, A., Nakajima, T., \& Kokobun, M. (2005). Effect of source/sink ratio and cytokinin application on pod set in soybean. Plant Prod. Sci., 8, 139-144.

\section{Copyrights}

Copyright for this article is retained by the author(s), with first publication rights granted to the journal.

This is an open-access article distributed under the terms and conditions of the Creative Commons Attribution license (http://creativecommons.org/licenses/by/3.0/). 